\title{
How Stifling Debate Around Race, Genes and IQ Can Do Harm
}

\author{
Noah Carl ${ }^{1}$ \\ Published online: 28 April 2018 \\ (C) The Author(s) 2018
}

\begin{abstract}
It is often asserted that, when it comes to taboo topics like race, genes and IQ, scholars should be held to higher evidentiary standards or even censored entirely because of the harm that might result if their findings became widely known. There is held to be an asymmetry whereby the societal costs of discussing certain topics inevitably outweigh any benefits from doing so. This paper argues that no such asymmetry has been empirically demonstrated, and that stifling debate around taboo topics can itself do active harm. To the extent that the paper's argument has force, it cannot simply be taken for granted that, when in doubt, stifling debate around taboo topics is the ethical thing to do.
\end{abstract}

Keywords Race $\cdot$ Genes $\cdot$ IQ $\cdot$ Ethics $\cdot$ Free speech

To suppress free speech is a double wrong. It violates the rights of the hearer as well as those of the speaker -Frederick Douglas, 1860, A Plea for Free Speech in Boston being wrong are sufficiently high, then it is reasonable and responsible to ask for more evidence than is demanded in situations where mistakes are relatively innocuous

Likewise, Block and Dworkin (1974) write, ${ }^{1}$

We are not... saying that at all times or in all places investigation of racial genotypic differences in IQ scores should stop. What we are saying is that at this time, in this country, in this political climate, individual scientists should voluntarily refrain from the investigation of genotypic racial differences in performance on IQ tests

More recently, Gillborn (2016) writes, is held to be an asymmetry whereby the societal costs of discussing certain topics inevitably outweigh any benefits from doing so. For example, Kitcher (1985) writes,

Everybody ought to agree that, given sufficient evidence for some hypothesis about humans, we should accept that hypothesis whatever its political implications. But the question of what counts as sufficient evidence is not independent of the political consequences. If the costs of

Noah Carl

noah.carl@nuffield.ox.ac.uk

1 Nuffield College, New Road, Oxford OX1 1NF, UK
We need to move to a position where all research on human capabilities (whether involving genetics or not) is predicated on a clear statement that any assertion of fixed and inevitable inequalities in ability/intelligence between racial/ethnic groups is, by its nature, racist

Kourany (2016) goes further, calling for the creation of "a new National Science Advisory Board for Social Research" that would impose "tighter restrictions on race- and gender-

\footnotetext{
${ }^{1}$ Both this example and the example of Kitcher (1985) were taken from Cofnas (2016).
} 
related cognitive differences research". Her contention being that "scientists' right to freedom of research cannot be allowed to subvert other people's rights", in this case their "right to equality".

The belief that stifling debate around race, genes and IQ is necessary to prevent harm has led to scholars being mischaracterised, censored and even physically attacked. Numerous examples can be found in Pinker (2002; Ch. 6), Nyborg (2011), Winegard and Winegard (2015) and Warne et al. (2018). Let us consider just a few. Following the publication of his book Sociobiology, which applied concepts from evolutionary biology to human social behaviour, E.O. Wilson was accused of attempting to justify genocide by fellow academics and was subjected to a campaign of harassment by irate student activists; defamatory leaflets were handed out, his lectures were invaded and he was even doused with a jug of water (Pinker, 2002). After publishing an article in The Harvard Educational Review arguing that efforts to boost children's IQs and scholastic achievement were limited by their genetic endowments, Arthur Jensen was roundly denounced as a fascist, racist and elitist. In the months that followed, he was unable to open his mail, had to be escorted around the Berkeley campus by bodyguards and was eventually forced to move house (Nyborg, 2011). When Charles Murray co-authored his book The Bell Curve (with Richard Herrnstein), which discussed studies of race differences in IQ, he was excoriated for supposedly trying to demonstrate that blacks were genetically inferior to whites (Winegard and Winegard 2015). Twenty-three years later, Murray was invited to give a talk at Middlebury College about an unrelated book. Soon after the talk began, he was shouted down by a jeering mob of students, so the discussion was moved to another site and broadcast via live stream. Once the discussion had finished, Murray and his interviewer Alison Stanger (a liberal Democrat who disagreed with Murray) were accosted by a group of students. As Stanger (2017) recounts,

Most of the hatred was focused on Dr Murray, but when I took his right arm to shield him and to make sure we stayed together, the crowd turned on me. Someone pulled my hair, while others were shoving me. I feared for my life. Once we got into the car, protesters climbed on it, hitting the windows and rocking the vehicle whenever we stopped to avoid harming them. I am still wearing a neck brace, and spent a week in a dark room to recover from a concussion caused by the whiplash

The foregoing examples illustrate the violent lengths to which some people will go to in order to stifle debate around race, genes and IQ. Why does this area of research incite such vitriolic indignation? A likely reason, as Winegard and Winegard (2015) argue, is that for a large number of academics in the West, the notion of biological sameness between groups (classes, sexes, races) has become what Tetlock (2003) calls a 'sacred value' (and see Ginges et al., 2007). ${ }^{2}$ Sacred values possess at least two important properties. First, they are incommensurable with respect to instrumental values: no amount of a sacred value can be traded off for any amount of an instrumental value. And second, proposals to accept such trade-offs are met not merely with rejection, but with moral outrage. Because arguments such as Wilson's, Jensen's and Murray's clearly threaten the sacred value of biological sameness between groups, it is not enough simply to attack the arguments; the defenders of those arguments must be hounded, and their characters impeached.

Furthermore, there is a large body of research in psychology showing that people are quite bad at objectively appraising risk (Kahneman, 2011, Ch. 13). For example, we tend to be more afraid of snakes, spiders and large carnivores than of loaded guns, faulty electrical wires and driving without a seatbelt (Pinker, 1997, Ch. 6.) One particularly important source of error is the 'affect heuristic', whereby people judge things to have worse consequences if their mental images of those things are imbued with more negative emotional content. As Slovic et al. (2007) note, "activities associated with cancer are seen as riskier and more in need of regulation than activities associated with less dreaded forms of illness, injury, and death (e.g., accidents)". The existence of the 'affect heuristic' should give us pause before concluding that the degree of moral outrage associated with a phenomenon constitutes a good measure of how much risk that phenomenon actually poses to society.

Although a great many areas of science (e.g., the germ theory of disease, the chemistry of particulates, the psychology of manipulation) are open to misuse, there are few if anywhere the putative asymmetry between societal costs and scientific or other benefits is held to be as great as in the area of race, genes and IQ. Of course, the main concern among commentators who subscribe to this asymmetry is that evidence of a genetic contribution to IQ differences between human populations would be used by racists to justify oppression or exploitation of populations with lower average IQs. For example, if it were found that the difference in mean IQ between European Americans and African Americans is partly genetic, the difference would be in some sense fixed, and the worry is that racists would then have a justification for oppressing or exploiting African Americans. It goes without saying that this concern should be taken seriously; the possibility of an asymmetry between the costs and benefits of discussing race, genes and IQ is not one that should be dismissed out of hand.

However, this paper argues that no such asymmetry has been empirically demonstrated, and that stifling debate around

\footnotetext{
${ }^{2}$ Winegard et al. (2018) have dubbed this notion "equalitarianism".
} 
taboo topics can itself do active harm. ${ }^{3}$ To the extent that the paper's argument has force, it cannot simply be taken for granted that, when in doubt, stifling debate around taboo topics is the ethical thing to do. The paper makes three main claims: first, that equating particular scientific statements with racism effectively holds our morals hostage to the facts; second, that the 'blank slate' view of human nature also has pernicious moral implications; and third, that there are clear examples of where stifling debate has done material harm to both individuals and societal institutions.

\section{Holding Our Morals Hostage to the Facts}

The first way in which stifling debate around taboo topics can do harm is by holding our morals hostage to the facts. By equating particular scientific statements (e.g., "the difference in mean IQ between European Americans and African Americans may be partly genetic") with racism (e.g., "African Americans are genetically inferior to European Americans"), those seeking to stifle debate commit the moralistic fallacy of concluding that a statement cannot be true if it has unpleasant moral implications (Davis, 1978) ${ }^{4}$. And in doing so, they make a rather perverse assumption, namely that if the relevant scientific statements were ever shown to be true, then the unpleasant moral implications would be valid. Yet as Pinker (2002; Ch. 6) notes, "We should not concede that any foreseeable discovery about humans could have such horrible implications... political equality is a moral stance, not an empirical hypothesis". 5

Indeed, there is already substantial evidence that individuals differ from one another with respect to IQ at least partly for genetic reasons (Plomin and Deary, 2015; Sniekers et al., 2017; Hill et al., 2018). But of course, this does not justify oppression or exploitation of those who have lower IQs. Likewise, there is already substantial evidence that human populations differ from one another with respect to traits like height, weight, bone density, muscle fibre distribution, lactose tolerance, thermogenic capacity and resistance to disease at least partly for genetic reasons (Epstein, 2014; Winegard et al., 2017). Yet, once again, this does not justify oppression or exploitation of populations who have lower means on these traits. Note that it is not being asserted that a

\footnotetext{
3 The present paper focuses on the harm done by stifling debate around race, genes and IQ. In a separate paper, Jeffrey and Shackelford (2017) examine "the benefits of knowing more about variance in intelligence" and put forward a "tentative case that the benefits outweigh the costs".

${ }^{4}$ It should be noted that not all of those who have sought to stifle debate around race, genes and IQ are guilty of this fallacy.

${ }^{5}$ Singer (2007) makes precisely the same point when he says, "no matter what the facts on race and intelligence turn out to be, they will not justify racial hatred, nor disrespect for people of a different race."
}

genetic contribution to racial gaps in IQ has been conclusively demonstrated, but rather that such a finding would not have a qualitatively different epistemological status from the recent finding that, say, genes associated with increased height ${ }^{6}$ are elevated in Northern Europeans relative to Southern Europeans (Turchin et al., 2012; Robinson et al., 2015).

The point that we should not hold our morals hostage to the facts has been made over and over again by scholars interested in race, genes and IQ. For example, Wilson (1978) stated,

Given that humankind is a biological species, it should come as no shock to find that populations are to some extent genetically diverse in the physical and mental properties underlying social behaviour. A discovery of this nature does not vitiate the ideals of Western civilisation. We are not compelled to believe in biological uniformity in order to affirm human freedom and dignity

Similarly, Jensen (1972) stated,

We must clearly distinguish between research on racial differences and racism. Racism implies hate or aversion and aims at denying equal rights and opportunities to persons because of their racial origin... But to fear research on genetic differences in abilities is, in a sense, to grant the racist's assumption: that if it should be established beyond reasonable doubt that there are biologically or genetically conditioned differences in mental abilities among individuals or groups, then we are justified in oppressing or exploiting those who are most limited in genetic endowment. This is, of course, a complete non sequitur

Herrnstein and Murray (1994, Ch. 13) stated,

Nothing seems more fearsome to many commentators than the possibility that ethnic and race differences have any genetic component at all. This belief is a fundamental error. Even if the differences between races were entirely genetic (which they are surely not), it should make no practical differences in how individuals deal with each other. The real danger is that the elite wisdom on ethnic differences - that such differences cannot exist-will shift to opposite and equally unjustified extremes. Open and informed discussion is the one certain

\footnotetext{
${ }^{6}$ Note also that height, just like IQ, is a socially salient trait. It has a robust positive association with individual income (Tyrell et al., 2016), and taller men are considered more attractive than shorter men (Nettle, 2002).
} 
way to protect society from the dangers of one extreme view or the other

As far back as the 1960s, one of the founding fathers of the 'modern synthesis' Ernst Mayr (1963) stated,

Equality in spite of evident non-identity is a somewhat sophisticated concept and requires a moral stature of which many individuals seem to be incapable. They rather deny human variability and equate equality with identity. Or they claim that the human species is exceptional in the organic world in that only morphological characters are controlled by genes and all other traits of the mind or character are due to "conditioning" or other non-genetic factors... An ideology based on such obviously wrong premises can only lead to disaster. Its championship of human equality is based on a claim of identity. As soon as it is proved that the latter does not exist, the support of equality is likewise lost

And in a recent New York Times op-ed, geneticist David Reich (2017) stated,

I am worried that well-meaning people who deny the possibility of substantial biological differences among human populations are digging themselves into an indefensible position, one that will not survive the onslaught of science. I am also worried that whatever discoveries are made - and we truly have no idea yet what they will be - will be cited as "scientific proof" that racist prejudices and agendas have been correct all along, and that those wellmeaning people will not understand the science well enough to push back against these claims.

As the quotes from Jensen, Mayr and Reich hint at, equating particular scientific statements with racism is not merely logically fallacious, but potentially unethical too. The reason being that it may end up encouraging precisely the behaviour that it aims to forestall. Suppose for the sake of argument that, one day in the future, evidence for a genetic contribution to psychological differences between human populations becomes so overwhelming that it cannot be reasonably denied. Note that there is nothing in science which rules this possibility out (Flynn, 2017). If between now and then, anyone who claims that genes might contribute to psychological group differences is pilloried as a 'racist', when the evidence eventually does become overwhelming, a much greater number of people are likely to take it as "scientific proof that racism was right all along". By contrast, if instead it is continuously asserted that "political equality is a moral stance, not an empirical hypothesis" - to quote Pinker once again - there is arguably much less danger of any discovery being taken as "scientific proof of racism".

The distinction between facts on the one hand, and values on the other, goes back at least to David Hume (1739; Bk. 3, Pt. 1), who demonstrated that propositions about what ought to be the case cannot be derived from propositions about what is the case (and see Moore, 1903, Ch. 1). In other words, no normative conclusion is implied by any positive proposition except in conjunction with an auxiliary normative proposition. For example, take the normative conclusion "whites are justified in oppressing and exploiting blacks". There is no pair of positive propositions from which this conclusion can be validly deduced. For example, the argument "blacks have a lower mean IQ than whites; therefore whites are justified in oppressing and exploiting blacks" is obviously invalid. Indeed, it is not even a syllogism. The conclusion "whites are justified in oppressing and exploiting blacks" can only be derived from the premise "blacks have a lower mean IQ than whites" in conjunction with another normative proposition, namely that "races with higher average IQs are justified in oppressing or exploiting races with lower average IQs". And there is of course no scientific evidence that could be adduced in support of that proposition. To summarise, particular scientific findings (e.g., that variation in IQ is partly genetic) are logically independent of particular normative conclusions (e.g., that people should not be exploited).

One possible objection to the preceding argument goes as follows. The discovery of a genetic contribution to, say, race differences in crime rates would seem to provide a strong Bayesian rationale for policies like racial profiling (e.g., stopping and searching black youths more often than white youths), which many people believe are unethical (see Risse and Zeckhauser, 2004; Sesardić, 2018). Insofar as this is the case, can it really be said that scientific findings are logically independent of normative conclusions? Taking 'independent' to mean 'not logically deducible from', yes it can. Just because something is 'rational' does not mean it is necessarily ethical. Indeed, discriminating on the basis of group differences is 'rational' regardless of whether those differences are genetic or environmental in origin, so the fact that racial profiling has already been criticised (i.e., has been criticised in a context where race differences in crime rates are almost universally assumed to be environmental) illustrates that many people accept the principle that something can be unethical even when it is 'rational'. Another point worth making is that racial profiling is fundamentally different from the kinds of oppression and exploitation that were meted out by racists in the past. As Sesardić (2018) notes, the police already profile men (who are much more likely to commit crime than women), but most people do not see any problem with this. Moreover, several black scholars have pointed out that the primary beneficiaries of racial profiling are the law-abiding black people who live in 
the neighbourhoods where black criminals operate (e.g., Riley, 2015, Ch. 3; Williams, 2017).

Furthermore, some radical political philosophies such as 'luck egalitarianism' are arguably just as easy to reconcile with the findings of differential psychology and behavioural genetics as any 'elitist' political philosophy (Dworkin, 1981a,b; Cohen, 1989; Anderson, 1999; Knight, 2013). ${ }^{7}$ For example, the philosopher Ronald Dworkin (1981a,b) drew a distinction between 'tastes and ambitions' on the one hand and 'endowments' on the other (see Lamont and Favor, 2017). An individual's tastes and ambitions comprise all the choices he makes that affect his material well-being, such as how hard to work, and whether to spend money frivolously or prudently. By contrast, his 'endowments' comprise all the handicaps or advantages he possesses due to circumstances beyond his control, such as his genes, his family's wealth or simple bad luck (e.g., getting hit by a car). According to Dworkin, material inequalities that arise due to differences in 'tastes and ambitions' may be justified, but those that arise due to differences in 'endowments' are not. So even if IQ were $100 \%$ genetic (which incidentally, it is not), since individuals cannot control the genes they will inherit, there is a relatively strong case to be made that inequalities arising due to differences in IQ (whether between individuals, classes or races) should be reduced or eliminated. Of course, this is not to say that luck egalitarianism is the correct moral theory, but simply that the findings of differential psychology and behavioural genetics need not be inconsistent with left-wing political ideals (see Dillow 2018).

\section{The Pernicious Implications of the Blank Slate}

The second way in which stifling debate around taboo topics can do harm is by promoting an alternative, 'blank slate' view of human nature, which in the past has proven no less pernicious in its supposed moral implications than the "hereditarian' view we have been discussing so far. This section quotes extensively from Pinker (2002, Ch. 8), who has elucidated the argument particularly well:

Some people have suggested to me that these grandiloquent arguments are just too fancy for the dangerous world we live in. Granted, there is evidence that people are different, but since data in the social sciences are never perfect, and since a conclusion of inequality might be used to the worst ends by bigots or Social Darwinists,

\footnotetext{
${ }^{7}$ As Rushton (1996) notes, "There are no necessary policies which flow from race research. The findings are compatible with a wide range of recommendations: from social segregation, through laissez-faire, to programs for the disadvantaged".
}

shouldn't we err on the side of caution and stick with the null hypothesis that people are identical? Some believe that even if we were certain that people differ genetically, we might still want to promulgate the fiction that they are the same, because it is less open to abuse.

This argument is based on the fallacy that the Blank Slate has nothing but good moral implications and a theory of human nature nothing but bad ones. In the case of human differences, as in the case of human universals, the dangers go both ways.

The first way in which the 'blank slate' view of human nature has been misused is as a justification for totalitarian efforts to 'remake humanity'. If there is no such thing as human nature, and individuals are not constrained by any kind of genetic endowment - so the arguments goes - those who exhibit undesirable traits can and should be 'perfected' through appropriately targeted state intervention. In the twentieth century's most repressive communist dictatorships, such intervention took a number of different forms, including forced labour programs, 're-education' camps and mass killings of the ones who proved incorrigible. As Pinker (2002, Ch. 8) notes, various communist ideologues' commitment to the 'blank slate' view of human nature is evidenced in the statements that they made:

Lenin endorsed Nikolai Bukharin's ideal of "the manufacturing of Communist man out of the human material of the capitalist age." Lenin's admirer Maxim Gorky wrote, "The working classes are to Lenin what minerals are to the metallurgist" and, "Human raw material is immeasurably more difficult to work with than wood" (the latter while admiring a canal built by slave labor). We come across the metaphor of the blank slate in the writings of a man who may have been responsible for sixty-five million deaths:

"A blank sheet of paper has no blotches, and so the newest and most beautiful words can be written on it, ." -Mao Zedong

And we find it in a saying of a political movement that killed a quarter of its countrymen:

"Only the newborn baby is spotless."

-Khmer Rouge slogan

The second way in which the 'blank slate' view of human nature has been misused is as a justification for persecution or genocide of 'successful' groups within society. According to this line of argument, if all groups start out identical, but some 
end up wealthier than others, then those who managed to accrue more wealth must have done so through nefarious means; they must have been more cunning, more avaricious or more sneaky than their rivals. Throughout the last two centuries, numerous ethnic groups and social classes have been persecuted because their success was taken as evidence of their wickedness: 'bourgeois peasants' in the Soviet Union; literate professionals in Cambodia; 'rich peasants' in Mao's China; the Indians in Uganda; the Chinese in Indonesia; the Armenians in Turkey; the Igbos in Nigeria; and the Jews in Europe, Russia and the Middle East (Pinker, 2002, Ch. 8; and see Cofnas, 2017).

Of course, the fact that the 'blank slate' view of human nature has been used to justify crimes such as genocide, forced labour and mass population displacement does not imply that the 'hereditarian' view is correct. Nor does it imply that the 'hereditarian' view has not also been grossly misused (most appallingly, by the Nazis). However, it does call into question the putative asymmetry whereby the societal costs of discussing genes, race and IQ are assumed to inevitably outweigh any benefits from doing so. As Pinker (2002, Ch. 8) notes, the "realization that government-sponsored mass murder can come from an anti-innatist belief system as easily as from an innatist one upends the postwar understanding that biological approaches to behavior are uniquely sinister".

\section{Material Harm Done by Stifling Debate}

Evidence presented in this section illustrates how stifling debate around taboo topics can do harm by leading scholars to ignore salient aspects of phenomena, by causing authorities to "sweep problems under the rug", and by inciting a backlash from enraged dissidents. First of all, consider race differences in optimal medicine. Back in the 1990s, Rushton (1996) pointed out that the medical needs of people from different racial backgrounds are almost certainly not identical (and see Rushton and Jensen, 2005). In particular, he noted that

Just as women doctors have advocated that to conceptualize women as being the same as men leads to a neglect of women's problems and their treatment (e.g., premenstrual symptoms and menopause and hormone replacement therapy), so Black doctors are increasingly becoming concerned that treating Blacks the same as Whites is to neglect Black problems

And indeed, Rushton's contention has been borne out by subsequent evidence (see Taylor and Ellis, 2002; Burroughs et al., 2002; Ramamoorthy et al., 2015). For example, in their 2002 review of the literature, Burroughs et al. concluded that

Pharmacogenetic research in the past few decades has uncovered significant differences among racial and ethnic groups in the metabolism, clinical effectiveness, and side-effect profiles of many clinically important drugs. These differences must be taken into account in the design of cost management policies such as formulary implementation, therapeutic substitution and step-care protocols

To deny the existence of 'race', or to insist that it is a wholly 'social construct', as many critics of the 'hereditarian' view of human nature do (see Wade, 2014, Ch. 5; Winegard et al., 2017; Sesardić, 2005, Ch. 4), is to commit oneself to an erroneous view of modern medicine, one which could conceivably come at the cost of people's lives.

The remaining two examples in this section do not pertain directly to the topic of race, genes and IQ. But they illustrate how stifling debate around taboo topics through 'political correctness' can do material harm to both individuals and societal institutions. First, it has emerged in Britain over the last few years that hundreds of vulnerable girls were systematically 'groomed' and in some cases violently gang-raped by groups of men from their local areas (e.g., Jay, 2013). Such cases have been reported in Aylesbury, Banbury, Bristol, Derby, Halifax, Keighley, Newcastle, Oxford, Peterborough, Rochdale, Telford and Rotherham. One of the salient facts about all these cases is that the vast majority of perpetrators ${ }^{8}$ were men of South Asian origin, whereas the victims were mostly White British girls (Rafiq and Adil, 2017). Since the cases began emerging, a number of independent government reports have been published (Jay, 2013; House of Commons, 2013; Bedford, 2015). These reports explain how various parties (such as the police, the social services and the local council) failed to intervene to stop the abuse because of misplaced concerns about 'political correctness' or for fear of being called 'racist'. ${ }^{9}$ For example, Jay (2013), who led the independent inquiry into sexual abuse in Rotherham, notes:

Several staff described their nervousness about identifying the ethnic origins of perpetrators for fear of being

\footnotetext{
${ }^{8}$ Researchers from the think tank Quilliam analysed data on grooming gang cases in the UK since 2005 and concluded that $84 \%$ of offenders were men of South Asian (mostly Pakistani) origin, despite the fact that South Asians make up no more than $7 \%$ of the British population.

${ }^{9}$ Similarly, in his review into electoral fraud in Britain, Sir Eric Pickles (2016) acknowledged concerns that "state institutions had turned a blind eye to such behavior because of 'politically correct' over-sensitivities about ethnicity and religion" (and see Carl, 2017).
} 
thought racist; others remembered clear direction from their managers not to do so

Likewise, Bedford (2015), who led the independent inquiry into sexual abuse in Oxfordshire, notes:

A parent told a police station about information provided by the daughter and queried why no immediate arrests were being made. The parent says the desk officer responded by saying that such arrests could not simply be made on such information and that the Police were also under pressure not to appear institutionally racist

The House of Commons report published in June of 2013 including the following among its list of recommendations for how to prevent future abuse:

It is important that police, social workers and others be able to raise their concerns freely, without fear of being labelled racist

The evidence from grooming gangs in Britain illustrates that throwing around unsubstantiated charges of 'racism' can create a climate of fear in which people feel too paralysed to act, and that insofar as this as this is the case, doing so should not be considered a sensible precaution, or even a mild nuisance, but a potentially unethical thing to do. Of course, it does not follow that there should be open season to make insulting or offensive remarks about ethnic minorities. The point is that there are costs as well as benefits to levelling accusations of 'racism', and that noticing patterns in the data should be clearly demarcated from intentionally denigrating whole communities.

Finally, it seems safe to assume that most of the people who are not already convinced by the arguments in this paper are unlikely to be supporters of US President Donald Trump (see Schaffner et al., 2017; Pettigrew, 2017). They would presumably, and indeed with some justification, regard his election as something that has done material harm to both individuals (e.g., illegal/undocumented immigrants) and societal institutions (e.g., the Office of the Presidency). It is therefore noteworthy that opposition to 'political correctness' appears to have been a major contributor to his election (Goldberg, 2018). One Trump supporter told a journalist at Reason magazine (Soave, 2016), "This blind adherence to political correctness was my main issue in the recent political arena". And another told the Washington Post (2016), "I am a gay millennial woman and I voted for Donald Trump because I oppose the political correctness movement". Furthermore, in a poll taken prior to the presidential election, Pew Research asked Americans whether "too many people are easily offended these days over the language that others use" (Fingerhut, 2016). A full $83 \%$ of Trump supporters agreed, compared to only $39 \%$ of Clinton supporters. Using multivariate analysis, Goldberg (2018) found that opposition to 'political correctness' remained a significant predictor of support for Trump even after controlling for several measures of prejudice, as well as attitudes to immigration. And in a recent experimental study, Conway et al. (2017) observed that priming respondents with a vignette about 'political correctness' led to a significant rise in support for Trump, but no rise in support for Clinton. According to the authors, their study "provides evidence that norms that are designed to increase the overall amount of positive communication can actually backfire by increasing support for a politician who uses extremely negative language that explicitly violates the norm". To the extent that many people concerned about the interests of disadvantaged groups regard the election of Donald Trump as a negative outcome (something which seems altogether plausible), the evidence presented above suggests that stifling debate around taboo topics through 'political correctness' may very well be counter-productive.

\section{Conclusion}

It is often asserted that, when it comes to taboo topics like race, genes and IQ, scholars should be held to higher evidentiary standards or even censored entirely because of the harm that might result if their findings became widely known. There is held to be an asymmetry whereby the societal costs of discussing certain topics inevitably outweigh any benefits from doing so. This paper argued that no such asymmetry has been empirically demonstrated, and that stifling debate around taboo topics can itself do active harm. To the extent that the paper's argument has force, it cannot simply be taken for granted that, when in doubt, stifling debate around taboo topics is the ethical thing to do. The argument comprised three main claims: first, that equating particular scientific statements with racism effectively holds our morals hostage to the facts; second, that the 'blank slate' view of human nature also has pernicious moral implications; and third, that there are clear examples of where stifling debate around taboo topics has done material harm to both individuals and societal institutions.

An important caveat is that the paper did not show that the societal benefits of discussing races, genes and IQ actually do outweigh the costs. It simply pointed out that the asymmetry assumed by those seeking to stifle debate has never been empirically demonstrated, and that there are in fact a number of ways in which stifling debate can do active harm. Consequently, the paper's overall conclusion was not that stifling debate is necessarily an unethical thing to do. Rather, it was a slightly weaker claim, namely that one cannot take for granted that stifling debate is the ethical thing to do. This 
weaker claim seems eminently reasonable, given that - at the very least - there are now a number of arguments for stifling debate around taboo topics (Kitcher, 1985; Block and Dworkin, 1974; Gillborn, 2016; Kourany, 2016), as well as a number of arguments against doing so, including the ones advanced here (and see Pinker, 2002; Flynn, 2017; Jeffrey and Shackelford, 2017).

Going forward, what steps can be taken to increase the quality of debate around taboo topics like race, genes and IQ? Most importantly, it should be reaffirmed that no normative conclusions follow from any particular scientific findings, and that holding our morals hostage to the facts is a great mistake (Pinker, 2002, Ch. 6). As noted above, evidence suggests that individuals differ from one another with respect to IQ at least partly for genetic reasons, but this does not justify oppression or exploitation of those who have lower IQs. Evidence also suggests that human populations differ from one another with respect to numerous physiological traits at least partly for genetic reasons, but this does not justify oppression or exploitation of populations who have lower means on these traits. Consequently, if it were one day conclusively demonstrated that genes contribute to psychological differences between human populations, it would not suddenly become justified to oppress or exploit the populations who scored lower on those psychological traits (Winegard et al., 2017). Admitting the arguments in this paper, another step that can be taken to increase the quality of debate is to encourage persons who disagree with one another to collaborate on a piece of research that might resolve their dispute (see Duarte et al., 2015).

It is worth ending with the words of philosopher Singer, 2007), who remarked in relation to the present debate, that "when faced with... major social problems, a preference for ignorance over knowledge is difficult to defend".

Acknowledgements I would like to thank Jam Kraprayoon, Nathan Cofnas, Benjamin Winegard and one anonymous reviewer for comments that improved the manuscript.

Open Access This article is distributed under the terms of the Creative Commons Attribution 4.0 International License (http:// creativecommons.org/licenses/by/4.0/), which permits unrestricted use, distribution, and reproduction in any medium, provided you give appropriate credit to the original author(s) and the source, provide a link to the Creative Commons license, and indicate if changes were made.

\section{References}

Anderson, E. S. (1999). What is the point of equality? Ethics, 109, 287-337. Bedford, A. (2015). Serious case review into child sexual exploitation in Oxfordshire: from the experiences of children A, B, C, D, E, and F. Oxfordshire Safeguarding Children Board, published online.

Block, N. J., \& Dworkin, G. (1974). IQ, heritability and inequality, part 2. Philosophy \& Public Affairs, 4, 40-99.
Burroughs, V. J., Maxey, R. W., \& Levy, R. (2002). Racial and ethnic differences in response to medicines: towards individualized pharmaceutical treatment. Journal of the National Medical Association, 94, 1-26.

Carl, N. (2017). Ethnicity and electoral fraud in Britain. Electoral Studies, $50,128-136$.

Cofnas, N. (2016). Science is not always "self-correcting": fact-value conflation and the study of intelligence. Foundations of Science, $21,477-492$

Cofnas, N. (2017). Judaism as a group evolutionary strategy: a critical analysis of Kevin MacDonald's theory. Human Nature, early online view.

Cohen, G. A. (1989). On the currency of egalitarian justice. Ethics, 99, 906-944.

Conway, L.G., Repke, M.A. \& Houck, S.C. (2017). Donald Trump as a cultural revolt against perceived communication restriction: priming political correctness norms causes more trump support. Journal of Social and Political Psychology, 2195-3325, published online.

Davis, B. B. (1978). The moralistic fallacy. Nature, 272, 390.

Dillow, C. (2018). Genes \& The Left. Stumbling and mumbling, January 16 , published online.

Duarte, J. L., Crawford, J. T., Stern, C., \& Haidt, J. (2015). Political diversity will improve social psychological science. Behavioural and Brain Sciences, 38, 1-58.

Dworkin, R. (1981a). What is equality? Part 1: equality of welfare. Philosophy and Public Affairs, 10, 283-345.

Dworkin, R. (1981b). What is equality? Part 2: equality of resources. Philosophy and Public Affairs, 10, 185-246.

Epstein, D. (2014). The sports gene: inside the science of extraordinary athletic performance. London, UK: Penguin.

Fingerhut, H. (2016). In 'political correctness' debate, most Americans think too many people are easily offended. Pew Research, published online.

Flynn, J. (2017). Academic freedom and race: You ought not to believe what you think may be true. Journal of Criminal Justice, in press.

Ginges, J., Atran, S., Medin, D., \& Shikaki, M. (2007). Sacred bounds on rational resolution of violent political conflict. PNAS, 104, 7357-7360.

Gillborn, D. (2016). Softly, softly: genetics, intelligence and the hidden racism of the new geneism. Journal of Education Policy, 31, 365-388.

Goldberg, Z. (2018). Serwer error: misunderstanding Trump voters. Quillette, January 1, published online.

Gottfredson, L. S. (2010). Lessons in academic freedom as lived experience. Personality and Individual Differences, 49, 272-280.

Herrnstein, R. J., \& Murray, C. (1994). The bell curve: intelligence and class structure in American life. New York City, NY: Free Press.

Hill, W.D., Marioni, R.E., Maghzian, O., Ritchie, S.J., Hagenaars, S.P. et al. (2018). A combined analysis of genetically correlated traits identifies 187 loci and a role for neurogenesis and myelination in intelligence. Molecular Psychiatry, published online.

House of Commons. (2013). Child sexual exploitation and the response to localised grooming: follow-up, Second Report of Session 201314. House of Commons Home Affairs Committee, published online.

Hume, D. (1739). A treatise of human nature. London, UK: John Noon.

Jay, A. (2013). Independent inquiry into child sexual exploitation in Rotherham. Rotherham Metropolitan Borough Council, published online.

Jeffrey, A.J. \& Shackelford, T.K. (2017). Moral positions on publishing race differences in intelligence. Journal of Criminal Justice, in press.

Jensen, A. (1972). Genetics and education. New York City, NY: Harper \& Row Publishers.

Kahneman, D. (2011). Thinking, fast and slow. New York City, NY: Farrar, Straus and Giroux.

Kitcher, P. (1985). Vaulting ambition: sociobiology and the quest for human nature. Cambridge, MA: MIT Press.

Knight, C. (2013). Luck egalitarianism. Philosophy Compass, 8(10), 924-934.

Kourany, J. A. (2016). Should some knowledge be forbidden? The case of cognitive differences research. Philosophy of Science, 83, 779-790. 
Lamont, J. \& Favor, C. (2017). Distributive justice: equality of opportunity and luck egalitarianism. Stanford Encyclopaedia of Philosophy, published online.

Mayr, E. (1963). Animal species and evolution. Cambridge, MA: Harvard University Press.

Moore, G. E. (1903). Principia ethica. Cambridge, UK: Cambridge University Press.

Nettle, D. (2002). Height and reproductive success in a cohort of British men. Human Nature, 13, 473-491.

Nyborg, H. (2011). The greatest collective scientific fraud of the 20th century: the demolition of differential psychology and eugenics. Mankind Quarterly, 51, 241-268.

Pettigrew, T.F. (2017). Social psychological perspectives on trump supporters. Journal of Social and Political Psychology, 2195-3325, published online.

Pickles, Sir Eric. (2016). Securing the ballot: report of Sir Eric Pickles' review into electoral fraud. UK Government, published online.

Pinker, S. (1997). How the mind works. New York City, NY: W.W. Norton \& Company.

Pinker, S. (2002). The blank slate: the modern denial of human nature. London, UK: Penguin Books.

Plomin, R., \& Deary, I. (2015). Genetics and intelligence differences: five special findings. Molecular Psychiatry, 20, 98-108.

Rafiq, H. \& Adil, M. (2017). Group based child sexual exploitationdissecting grooming gangs. Quilliam Foundation, published online.

Ramamoorthy, A., Pacanowski, M. A., Bull, J., \& Zhang, L. (2015). Racial/ethnic differences in drug disposition and response: review of recently approved drugs. Clinical Pharmacology \& Therapeutics, 97, 263-273.

Reich, D. (2017). How genetics is changing our understanding of 'race'. New York Times, March 23, published online.

Risse, M., \& Zeckhauser, R. (2004). Racial profiling. Philosophy \& Public Affairs, 32, 131-170.

Riley, J. L. (2015). Please stop helping us: how liberals make it harder for blacks to succeed. New York City, NY: Encounter Books.

Robinson, M. R., Hemani, G., Medina-Gomez, C., Mezzavilla, M., Esko, T., et al. (2015). Population genetic differentiation of height and body mass index across Europe. Nature Genetics, 47, 1357-1362.

Rushton, J. P. (1996). Political correctness and the study of racial differences. Journal of Social Distress and the Homeless, 5, 213-229.

Rushton, J. P., \& Jensen, A. R. (2005). Thirty years of research on race differences in cognitive ability. Psychology, Public Policy and Law, 11, 235-294.

Schaffner, B.F., MacWilliams, M. \& Nteta, T. (2017). Explaining white polarization in the 2016 vote for president: the sobering role of racism and sexism. Working Paper, published online.
Sesardić, N. (2005). Making sense of heritability. Cambridge, UK: Cambridge University Press.

Sesardić, N. (2018). Is racial profiling a legitimate strategy in the fight against violent crime? Philosophia, 1-19.

Singer, P. (2007). Should we talk about race and intelligence? Project Syndicate, November 1, published online.

Slovic, P., Finucane, M. L., Peters, E., \& MacGregor, D. G. (2007). The affect heuristic. European Journal of Operational Research, 177, $1333-1352$.

Sniekers, S., Stringer, S., Watanabe, K., Jansen, P. R., Coleman, J. R. I., et al. (2017). Genome-wide association meta-analysis of 78,308 individuals identifies new loci and genes influencing human intelligence. Nature Genetics, 49, 1107-1112.

Soave, R. (2016). Yes, political correctness helped elect trump: what skeptics need to know. Reason, Hit \& Run Blog, December 19, published online.

Stranger, A. (2017). Understanding the angry mob at Middlebury that gave me a concussion. The New York Times, March 13, published online.

Taylor, J. S., \& Ellis, G. R. (2002). Racial differences in responses to drug treatment: implications for pharmacotherapy of heart failure. American Journal of Cardiovascular Drugs, 2, 389-399.

Tetlock, P. E. (2003). Thinking the unthinkable: sacred values and taboo cognitions. Trends in Cognitive Sciences, 7, 320-324.

Turchin, M. C., Chiang, C. W. K., Palmer, C. D., Sankararaman, S., Reich, D., et al. (2012). Evidence of widespread selection on standing variation in Europe at height-associated SNPs. Nature Genetics, $44,1015-1019$.

Tyrell, J., Jones, S. E., Beaumont, R., Astley, C. M., Lovell, R., et al. (2016). Height, body mass index, and socioeconomic status: Mendelian randomisation study in UK Biobank. BMJ, 352, 1-10.

Wade, N. (2014). A troublesome inheritance: genes, race and human history. London, UK: Penguin.

Warne, R. T., Astle, M. C., \& Hill, J. C. (2018). What do undergraduates learn about human intelligence? An analysis of introductory psychology textbooks. Archives of Scientific Psychology, 6, 32-50.

Washington Post. (2016). Why I voted for Trump. Washington Post, Opinion, November 23, published online.

Winegard, B., \& Winegard, B. (2015). A social science without sacred values. Working Paper, published online.

Winegard, B., Winegard, B., \& Boutwell, B. (2017). Human biological and psychological diversity. Evolutionary Psychological Science, 3, 159-180.

Winegard, B.M., Clark, C.J. \& Hasty, C. (2018). Equalitarianism: a source of liberal bias. Working paper, published online.

Williams, W.E. (2017). Blacks suffer when police are undermined. The News Virginian, Opinion, February 19, published online.

Wilson, E. O. (1978). On human nature. Cambridge, MA: Harvard University Press. 